\title{
PENGGUNAAN USELEARN SEBAGAI METODE EVALUASI USABILITY UNTUK E-LEARNING
}

\author{
DIAN PALUPI RESTUPUTRI ${ }^{1}$ DAN WAHYU FITRIANDA MUFTI ${ }^{2}$ \\ ${ }^{1}$ Jurusan Teknik Industri, Universitas Muhammadiyah Malang ${ }^{1}$ \\ Jl. Raya Tlogomas 246 Malang 65141 \\ ${ }^{2}$ Jurusan Teknik Industri, Universitas Putra Indonesia "YPTK" \\ Jl. Raya Lubuk Begalung Padang \\ Surel: restuputri@yahoo.com
}

\begin{abstract}
ABSTRAK
Penelitian ini bertujuan untuk mengevaluasi website E-learning menggunakan metode Uselearn. Uselearn adalah metode evaluasi usability yang mana meninjau sistem E-learning dari perspektif kualitas dan usability. Kuesioner diberikan kepada partisipan yang berjumlah 101 orang. Responden diberikan kuesioner yang sesuai dengan 12 dimensi dari metode Uselearn. Structural Equation Modelling (SEM) digunakan untuk memvalidasi hasil kuesioner secara kuantitatif. Hasil yang didapat setelah pengolahan data menggunakan SEM terbentuk 10 dimensi usability baru yaitu Consistency and Functionality (CF), Error Prevention (EP), Visibility (VIS), Flexibility (FLEX), Accessibility (AC), Memorability (MEMO), Completeness (COM), Reducing Redudancy (RR), Interactivity, Feedback and Help (IFH), dan Assessment Strategy (AS). Dari analisis uselearn terhadap website E-learning didapat nilai indeks usability terendah untuk dimensi Interactivity Feedback and Help (IFH), Reducing Redudancy (RR), Completeness (COM) dan Error Prevention (EP). Perbaikan yang bisa dilakukan yaitu dengan merubah tampilan icon dan penambahan menu, serta pengaturan pada website E-learning.
\end{abstract}

Kata kunci: E-learning, evaluasi usability, uselearn, criticality metric

\begin{abstract}
This study aimed to evaluate E-learning using uselearn method. Uselearn is usability assessment method to assess E-learning from variable quality and usability. The questionnaire was given to 101 participants. The participants were given a questionnaire according with 12 dimensions of uselearn. Structural Equation Modelling (SEM) was used to validate the result of quantitative statistic. The results obtained after processing the data using SEM formed 10 new usability dimensions namely Consistency and Functionality (CF), Error Prevention (EP), Visibility (VIS), Flexibility (FLEX), Accessibility (AC), Memorability (MEMO), Completeness (COM ), Reducing redundancy (RR), Interactivity, Feedback and Help (IFH), and Assessment Strategy (AS). From the analysis obtained the lowest usability index values for the dimensions of Interactivity Feedback and Help (IFH), Reducing redundancy (RR), Completeness (COM) and Error Prevention (EP). Improvements that can be done is to improve the appearance of the icon and menu additions, as well as setting the E-learning website.
\end{abstract}

Key words : E-learning, usability assessment, uselearn, criticality metric

\section{PENDAHULUAN}

E-learning adalah suatu sistem yang dirancang untuk proses belajar dan mengajar yang memanfaatkan media elektronik khususnya internet sebagai sistem pembelajarannya (Oztekin dkk., 2010). Salah satu manfaat E-learning yaitu mempersingkat waktu pembelajaran sehingga lebih efektif dan efisien. E-learning mempermudah interaksi antar pengguna yang mencakup peserta didik dengan bahan atau materi, peserta didik dengan dosen atau guru atau instruktur maupun sesama peserta didik. Dari pengamatan yang dilakukan di lingkungan universitas, masih banyak pengguna E-learning baik dosen maupun 
mahasiswa yang mengalami kesulitan ketika mengakses website E-learning, sehingga proses belajar dan mengajar jarak jauh yang diharapkan bisa menjadi solusi pembelajaran menjadi tidak efektif (Wahono, 2007). Karena berbagai kesulitan yang ditemui oleh dosen maupun mahasiswa menyebabkan fasilitas E-learning yang tersedia di universitas jarang digunakan.

Dari sebuah studi yang dilakukan oleh Forrester Group tahun 2000 kepada 40 perusahaan besar menunjukkan bahwa sebagian besar pekerja (lebih dari 68\%) menolak untuk mengikuti pelatihan atau kursus yang menggunakan konsep E-learning (Dublin \& Cross, 2003). Ketika E-learning itu diwajibkan kepada mereka, 30\% menolak untuk mengikutinya. Sedangkan studi lain mengindikasikan bahwa dari orang-orang yang mendaftar untuk mengikuti E-learning, 50-80\% tidak pernah menyelesaikannya sampai akhir (Delio, 2000). Supaya sistem E-learning dapat memberikan manfaat bagi semua penggunanya, salah satu cara yang dapat dilakukan adalah melakukan evaluasi usability. Menurut Nielsen (1993), usability adalah ukuran kualitas pengalaman pengguna ketika berinteraksi dengan produk atau sistem seperti website, aplikasi software, teknologi bergerak, maupun peralatan-peralatan lain yang dioperasikan oleh pengguna. Usability dapat didefinisikan sebagai sejauh mana suatu produk dapat digunakan oleh pengguna dalam mencapai suatu tujuan pada lingkungan tertentu dengan efektif, efisien, dan mencapai kepuasan pengguna (ISO 9241-11, 1998).

Usability situs web didefinisikan sebagai atribut kualitas yang menilai seberapa mudah user interfaces digunakan (Nielsen, 2003) dan kejelasan, kesederhanaan, dan konsistensi dalam desain situs web, untuk memungkinkan pengguna melakukan tugas mereka dengan mudah (Harfoushi et al., 2012). Telah ada beberapa penelitian untuk mengevaluasi usability (Matera dkk., 2002; McGee, 2004), akan tetapi metode ini perlu ditingkatkan dalam banyak aspek, misalnya mereka tidak mengusulkan metode validasi kuantitatif melalui checklist untuk menghitung skor tunggal dari indeks usability. Oztekin dkk. (2010) membuat suatu penelitian yang bertujuan untuk mengevaluasi E-learning berdasarkan dimensi usability dan dimensi kualitas yang disebut dengan uselearn. Pada penelitian ini menggunakan situs E-learning pada salah perguruan tinggi ternama di Indonesia, karena nampaknya dari aspek usability belum terkaji dengan baik. Adapun tujuan yang ingin dicapai pada penelitian ini adalah mengevaluasi usability dari E-learning menggunakan metode uselearn.

\section{METODE}

Usability adalah salah satu aspek ergonomi untuk menilai apakah suatu produk mudah digunakan atau tidak berdasarkan pengukuran variabel tertentu. Uselearn adalah metode evaluasi usability yang mana menggabungkan dimensi usability dan kualitas untuk E-learning dengan menggunakan checklist (Oztekin dkk., 2010).

Pengumpulan data dilakukan dengan menganalisis website blendedlearning yaitu situs E-learning dari salah satu perguruan tinggi negeri di kota Bandung. Responden yang digunakan berjumlah 101 mahasiswa dari perguruan tinggi tersebut yang pernah mengikuti perkuliahan menggunakan media E-learning. Responden diberikan kuesioner yang sesuai dengan 12 dimensi yang mengacu kepada penelitian Oztekin dkk. (2010). Ringkasan dari dimensi yang dikembangkan Oztekin dkk. (2010) untuk mengevaluasi usability pada sistem E-learning dapat dilihat pada Tabel 1. Pendekatan oleh Oztekin dkk. (2010) dipilih karena pendekatan ini merupakan yang paling komprehensif dan item pertanyaannya juga lebih singkat dan lebih mudah dimengerti.

Gambar 1 memperlihatkan langkah-langkah untuk menganalisis data uselearn. Setelah didapat data dari kuesioner, data tersebut kemudian dicari nilai mean dan standar deviasinya dari masing-masing dimensi pertanyaan. Nilai mean ini nantinya akan digunakan untuk mencari nilai inverse mean yang dipakai untuk menentukan nilai criticality metric. Kemudian data diolah 
menggunakan analisis Exploratory Factor Analysis (EFA) untuk memvalidasi hubungan antara dimensi item. Dari dimensi yang terbentuk kemudian dilakukan pembobotan dari masing-masing item melalui analisis CFA. Nilai pembobotan ini nantinya akan digunakan untuk mengetahui nilai indeks usability.

Tabel 1. Dimensi Usability

\begin{tabular}{l}
\hline Dimensi Usability \\
\hline Pencegahan kesalahan (Error Prevention) \\
Visibilitas (Visibility) \\
Fleksibilitas (Flexibility) \\
Manajemen Pembelajaran (Course \\
Management) \\
Interaktivitas, Umpan Balik dan Bantuan \\
(Interactivity, Feedback and Help) \\
Aksesibilitas (Accessibility) \\
Konsistensi dan Fungsionalitas (Consistency \\
and Functionality) \\
Strategi Penilaian (Assessment Strategy) \\
Kemudahan Mengingat (Memorability) \\
Kemudahan Penyelesaian (Completeness) \\
Estetika (Aesthetics) \\
Pengurangan Pengulangan (Reducing \\
Redudancy)
\end{tabular}

\section{HASIL DAN PEMBAHASAN}

Dari 101 responden, data kuesioner kemudian dicari nilai mean dan standar deviasinya dari masing-masing dimensi pertanyaan. Nilai mean ini nantinya akan digunakan untuk mencari nilai inverse of mean yang dipakai untuk menentukan nilai criticality metric. Tabel 2 merupakan hasil pengurutan dimensi berdasarkan nilai mean dari terendah ke tertinggi.

Setelah itu hasil kuesioner diolah menggunakan analisis Structural Equation Modeling (SEM) dengan bantuan program Lisrel 8.3. Exploratory Factor Analysis (EFA) dan Confirmatory Factor Analysis (CFA) digunakan untuk memvalidasi hubungan antara dimensi item. EFA merupakan analisis SEM yang digunakan untuk mengelompokkan dimensi berdasarkan matrik kedekatan. Sehingga, dari 12 dimensi yang telah ditentukan diawal berkurang menjadi 10 dimensi. Dimensi baru yang terbentuk adalah Consistency and Fungtionality (CF), Error Prevention (EP), Visibility (VIS), Flexibility (FLEX), Accessibility (AC), Memorability (MEMO),

Sumber : (Oztekin dkk., 2010)

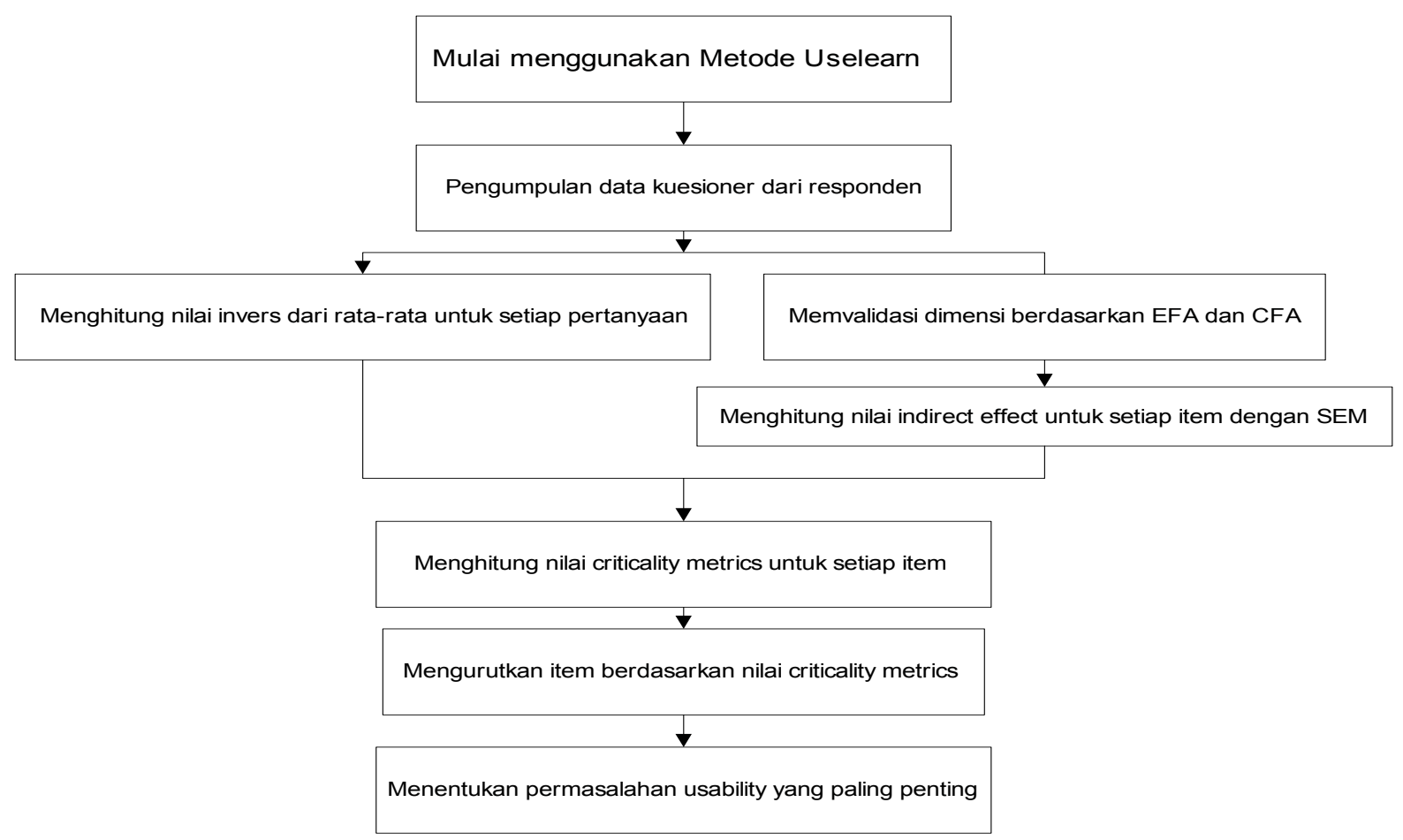

Sumber : (Oztekin dkk., 2010)

Gambar 1. Langkah-Langkah Analisis Data Uselearn 
Tabel 2. Statistik Deskriptif untuk Item Uselearn

\begin{tabular}{|c|c|c|}
\hline Items & Mean & Std Dev \\
\hline Completeness 2 & 2,06 & 0,31 \\
\hline Accessibility 1 & 2,23 & 0,51 \\
\hline Accessibility 2 & 2,27 & 0,53 \\
\hline Assessment Strategy 1 & 2,35 & 0,77 \\
\hline $\begin{array}{l}\text { Interactivity, Feedback, } \\
\text { Help } 2\end{array}$ & 2,50 & 0,83 \\
\hline Memorability 3 & 2,64 & 0,91 \\
\hline Completeness 3 & 2,66 & 0,84 \\
\hline Assessment Strategy 2 & 2,71 & 0,67 \\
\hline Accessibility 3 & 2,76 & 0,95 \\
\hline Memorability 4 & 2,87 & 1,00 \\
\hline $\begin{array}{l}\text { Consistency and } \\
\text { Functionality } 5\end{array}$ & 2,89 & 0,84 \\
\hline Memorability 1 & 2,91 & 1,08 \\
\hline Flexibility 3 & 2,91 & 0,65 \\
\hline Visibility 5 & 2,94 & 0,88 \\
\hline Visibility 2 & 3,02 & 1,10 \\
\hline Flexibility 1 & 3,03 & 1,03 \\
\hline Visibility 3 & 3,06 & 1,18 \\
\hline Error Prevention 3 & 3,15 & 1,13 \\
\hline $\begin{array}{l}\text { Consistency and } \\
\text { Functionality } 3\end{array}$ & 3,20 & 0,89 \\
\hline Accessibility 4 & 3,25 & 0,48 \\
\hline Error Prevention 1 & 3,26 & 0,76 \\
\hline Flexibility 2 & 3,26 & 0,89 \\
\hline $\begin{array}{l}\text { Consistency and } \\
\text { Functionality } 2\end{array}$ & 3,30 & 0,77 \\
\hline Visibility 4 & 3,33 & 0,97 \\
\hline Memorability 5 & 3,40 & 0,55 \\
\hline Visibility 1 & 3,43 & 0,71 \\
\hline Error Prevention 2 & 3,52 & 0,88 \\
\hline $\begin{array}{l}\text { Consistency and } \\
\text { Functionality } 1\end{array}$ & 3,60 & 0,53 \\
\hline Completeness 4 & 3,63 & 0,53 \\
\hline Reducing Redudancy 1 & 3,70 & 0,77 \\
\hline Memorability 2 & 3,76 & 0,69 \\
\hline $\begin{array}{l}\text { Consistency and } \\
\text { Functionality } 4\end{array}$ & 3,77 & 0,68 \\
\hline $\begin{array}{l}\text { Interactivity, Feedback, } \\
\text { Help } 1\end{array}$ & 3,82 & 0,64 \\
\hline Reducing Redudancy 2 & 4,00 & 0,71 \\
\hline Visibility 6 & 4,07 & 0,55 \\
\hline Completeness 1 & 4,14 & 0,35 \\
\hline
\end{tabular}

Completeness (COM), Reducing Redudancy (RR), Interactivity, Feedback and Help (IFH), dan Assessment Strategy (AS). Pengelompokan item pertanyaan yang didapat dari hasil EFA dapat dilihat pada Tabel 3.

Gambar 2 merupakan model penilaian uselearn setelah melalui proses analisis EFA. Kesepuluh dimensi yang terbentuk kemudian dilakukan pembobotan dari masing-masing item melalui analisis CFA. Nilai pembobotan ini nantinya akan digunakan untuk mengetahui nilai indeks usability. Dari nilai indeks usability ini akan dapat didisagregasikan menjadi tiga lowlevel dimensi uselearn yaitu efisien, efektif, dan kepuasan.

Dari hasil CFA, kemudian didapatkan nilai indirect effect yang nantinya akan digunakan untuk mengetahui nilai criticality metric. Nilai criticality metric digunakan untuk mengukur nilai indeks usability. Tabel 4 merupakan tabel nilai indeks usability yang didapatkan dari hasil analisis criticality metric kemudian ditampilkan dalam bentuk diagram. Nilai criticality metric didapat dari perkalian inverse mean dengan indirect effect menggunakan software SEM.

Penelitian ini bertujuan untuk mengevaluasi seberapa mudah website E-learning digunakan oleh mahasiswa. Hasil dari penelitian ini didapatkan permasalahan utama dalam mengoperasikan $E$-learning seperti yang terlihat di Gambar 3. Gambar 3 menunjukkan bahwa nilai tertinggi adalah Assessment Strategy 2 dengan pertanyaan "Apakah terdapat beberapa strategi penilaian untuk mengukur pengetahuan, skill, dan standar performansi?". Nilai Assessment Strategy 2 mendapatkan nilai yang paling tinggi, disebabkan karena terdapat kontrak perkuliahan antara dosen dan mahasiswa yang jelas, misalnya untuk forum diskusi mendapatkan nilai $5 \%$, untuk tugas $15 \%$, dan ujian tengah semester $30 \%$, ujian akhir semester $30 \%$, dan quiz $20 \%$.

Dari Tabel 5, dapat disimpulkan bahwa kelima item yang memiliki nilai terendah perlu diperbaiki. Misalnya pada item Interactivity, Feedback and Help1 (IFH1), dari hasil analisis IFH1 mendapat nilai terendah karena minimnya umpan balik dari dosen kepada mahasiswa pada blendedlearning, sehingga bisa diberikan suatu 
Tabel 3. Pengelompokan Item Pertanyaan Uselearn

\section{CONSISTENCY \& FUNCTIONALITY}

Consistency \& functionality 1

Consistency \& functionality 2

Consistency \& functionality 3

Consistency \& functionality 4

Consistency \& functionality 5

\section{VISIBILITY}

Visibility 1

Visibility 2

Visibility 3

Visibility 4

Visibility 5

Visibility 6

\section{MEMORABILITY}

Memorability 1

Memorability 2

Memorability 3

Memorability 4

Memorability 5

\section{ACCESSIBILITY}

Accessibility 1

Accessibility 2

Accessibility 3

Accessibility 4

\section{ERROR PREVENTION}

Error Prevention 1

Error Prevention 2

Error Prevention 3

\section{COMPLETENESS}

Completeness 1

Completeness 2

Completeness 3

Completeness 4

FLEXIBILITY

Flexibility 1
Apakah judul dan header yang bermacam-macam menggunakan bentuk yang konsisten?

Apakah icon, tombol, label dan link mempunyai tujuan yang jelas? Apakah interface menyediakan tombol "kembali" yang fungsinya untuk kembali ke layar sebelumnya?

Apakah terdapat label yang berguna dan link yang informatif untuk mendukung proses pembelajaran?

Dapatkah pengguna mengerti dengan mudah semua komponen dan menu di E-learning?

Apakah setiap tombol telah dikelompokkan dan diberi label?

Apakah setiap tombol memiliki fungsi yang jelas?

Apakah isi Mata Kuliah mempunyai link di homepage?

Apakah situs E-learning menyediakan informasi bagi mahasiswa dan memberikan link untuk informasi tersebut?

Apakah situs E-learning menyediakan sumber yang spesifik untuk mendukung pembelajaran mahasiswa secara online?

Apakah file mudah untuk di upload?

Apakah mahasiswa disediakan FAQ (Frequently Ask Question) dan Human support untuk memperoleh bantuan yang diperlukan?

Apakah informasi yang disajikan dapat diingat dengan mudah?

Apakah warna dan grafik yang digunakan telah sesuai sehingga mempermudah navigasi?

Apakah tampilan layar nyaman untuk dilihat?

Apakah untuk memodifikasi tindakan harus dilakukan berulangulang?

Apakah fitur layar mudah diatur sesuai dengan kebutuhan mahasiswa?

Apakah masalah kemudahan akses dibahas selama kuliah?

Apakah menu dapat dilihat dan diakses dengan mudah?

Apakah isi E-learning dapat dibuat dengan mudah dan digunakan kembali?

Dapatkah mahasiswa mengerti perintah dalam E-learning dan menyelesaikannya dengan mudah?

Dapatkah mahasiswa membatalkan apa yang sudah dipilih?

Apakah pesan peringatan dapat mencegah terjadinya error?

Apakah file mudah untuk di download dan dilihat?

Apakah jalur alternatif untuk isi pembelajaran dan aktifitas disediakan?

Apakah sistem E-learning meminta mahasiswa untuk memiliki kesiapan sebelum kelas online?

Apakah E-learning mudah untuk diatur dan mudah untuk dinavigasi?

Apakah kecepatan pada saat membuka website mata kuliah cukup tinggi? 
Lanjutan Tabel 3

Flexibility 2

Dapatkah mahasiswa menambah sumber daya dan isi ke E-learning dengan mudah?

Flexibility 3

Apakah tujuan instruksi dan strategi penilaian saling berhubungan?

INTERACTIVITY, FEEDBACK AND HELP

Interactivity, Feedback and

Help 1

Interactivity, Feedback and Help 2

ASSESSMENT STRATEGY

Assessment Strategy 1

Assessment Strategy 2

REDUCING REDUDANCY

Reducing Redudancy 1

Reducing Redudancy 2
Apakah situs E-learning menawarkan beberapa kesempatan untuk interaksi dan komunikasi diantara mahasiswa, dosen, dan isi situs E-learning?

Apakah terdapat feedback tentang kinerja mahasiswa yang disajikan pada waktu yang tepat?

Apakah mahasiswa diberikan informasi untuk mengetahui di menu mana dia berada?

Apakah terdapat beberapa strategi penilaian untuk mengukur pengetahuan, skill dan standar performansi?

Apakah kesulitan dalam menggunakan E-learning dapat berkurang dengan cara memberikan pilihan menu yang mudah dikenal? Apakah menu pilihan dalam E-learning dapat dilihat dengan mudah sehingga pengguna tidak harus mencari menu tersebut dan mencoba untuk mengingatnya?

Tabel 4. Kontribusi Masing-Masing Item Dimensi terhadap Indeks Usability Melalui Nilai Criticality Metric

\begin{tabular}{lccc}
\hline \multicolumn{1}{c}{ Indikator } & Inverse of mean & Indirect effect & $\begin{array}{c}\text { Criticality } \\
\text { metrix }\end{array}$ \\
\hline Consistency and Functionality 1 & 0,277 & 0,270 & 0,0750 \\
Consistency and Functionality 2 & 0,303 & 0,317 & 0,0961 \\
Consistency and Functionality 3 & 0,313 & 0,391 & 0,1223 \\
Consistency and Functionality 4 & 0,265 & 0,437 & 0,1159 \\
Consistency and Functionality 5 & 0,346 & 0,517 & 0,1788 \\
Visibility 1 & 0,292 & 0,483 & 0,1409 \\
Visibility 2 & 0,331 & 0,466 & 0,1544 \\
Visibility 3 & 0,327 & 0,303 & 0,0990 \\
Visibility 4 & 0,301 & 0,485 & 0,1459 \\
Visibility 5 & 0,340 & 0,462 & 0,1571 \\
Visibility 6 & 0,246 & 0,593 & 0,1458 \\
Memorability 1 & 0,344 & 0,308 & 0,1060 \\
Memorability 2 & 0,266 & 0,351 & 0,0933 \\
Memorability 3 & 0,378 & 0,389 & 0,1472 \\
Memorability 4 & 0,348 & 0,342 & 0,1191 \\
Memorability 5 & 0,294 & 0,534 & 0,1573 \\
Accessibility 1 & 0,449 & 0,186 & 0,0835 \\
Accessibility 2 & 0,441 & 0,276 & 0,1219 \\
Accessibility 3 & 0,362 & 0,387 & 0,1400 \\
Accessibility 4 & 0,308 & 0,385 & 0,1187 \\
Error Prevention 1 & 0,307 & 0,112 & 0,0343 \\
& & &
\end{tabular}


Lanjutan Tabel 4

\begin{tabular}{lccc}
\hline \multicolumn{1}{c}{ Indikator } & Inverse of mean & Indirect effect & $\begin{array}{c}\text { Criticality } \\
\text { metrix }\end{array}$ \\
\hline Error Prevention 2 & 0,284 & 0,259 & 0,0735 \\
Error Prevention 3 & 0,318 & 0,163 & 0,0517 \\
Completeness 1 & 0,242 & 0,117 & 0,0283 \\
Completeness 2 & 0,486 & 0,118 & 0,0572 \\
Completeness 3 & 0,375 & 0,293 & 0,1100 \\
Completeness 4 & 0,275 & 0,301 & 0,0828 \\
Flexibility 1 & 0,330 & 0,282 & 0,0932 \\
Flexibility 2 & 0,307 & 0,332 & 0,1021 \\
Flexibility 3 & 0,344 & 0,522 & 0,1795 \\
Interactivity, Feedback and Help 1 & 0,262 & 0,045 & 0,0116 \\
Interactivity, Feedback and Help 2 & 0,399 & 0,303 & 0,1208 \\
Assessment Strategy 1 & 0,426 & 0,441 & 0,1881 \\
Assessment Strategy 2 & 0,369 & 0,543 & 0,2000 \\
Reducing Redudancy 1 & 0,270 & 0,090 & 0,0244 \\
Reducing Redudancy 2 & 0,250 & 0,135 & 0,0338 \\
\hline
\end{tabular}

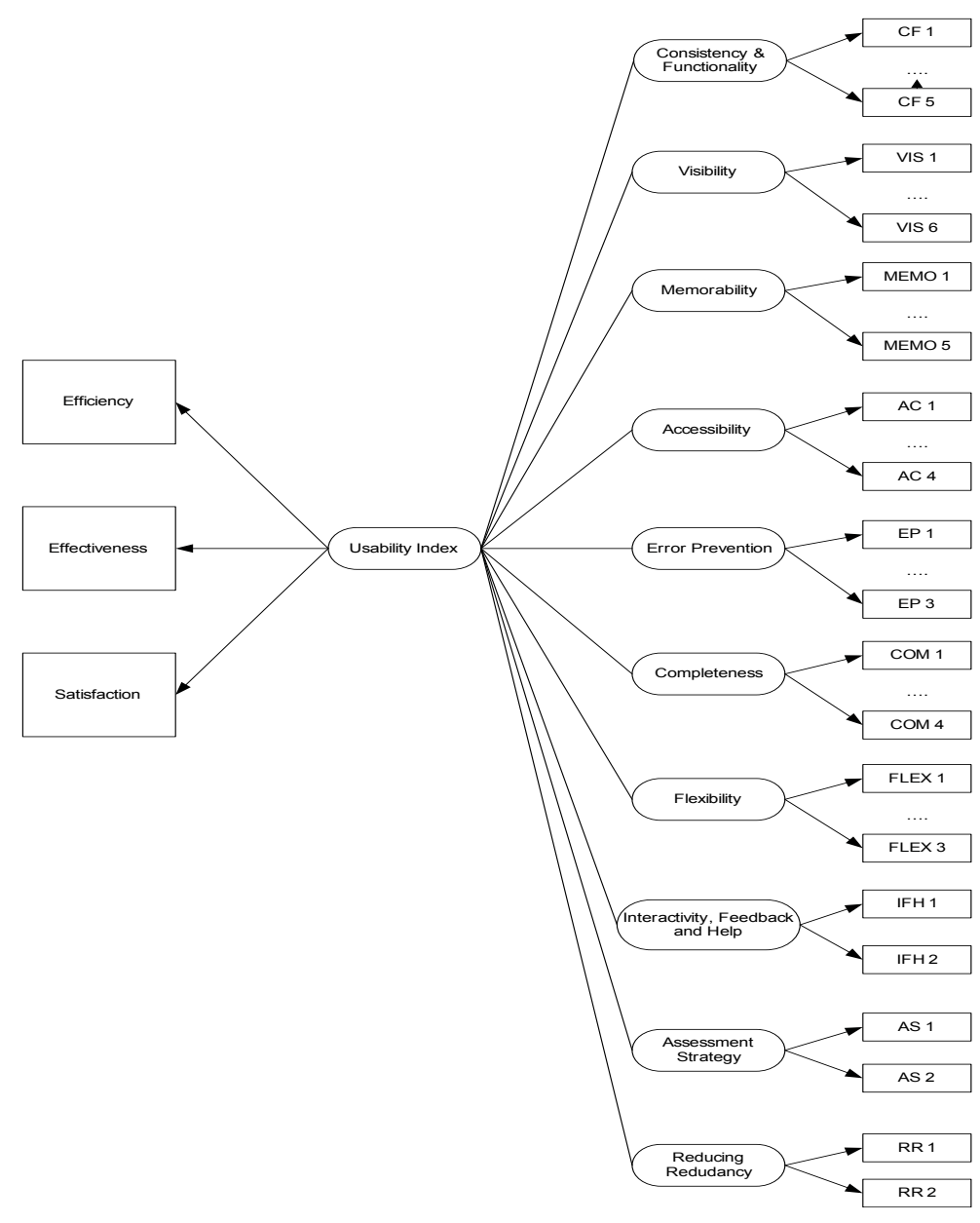

Gambar 2. Model Penilaian Uselearn 


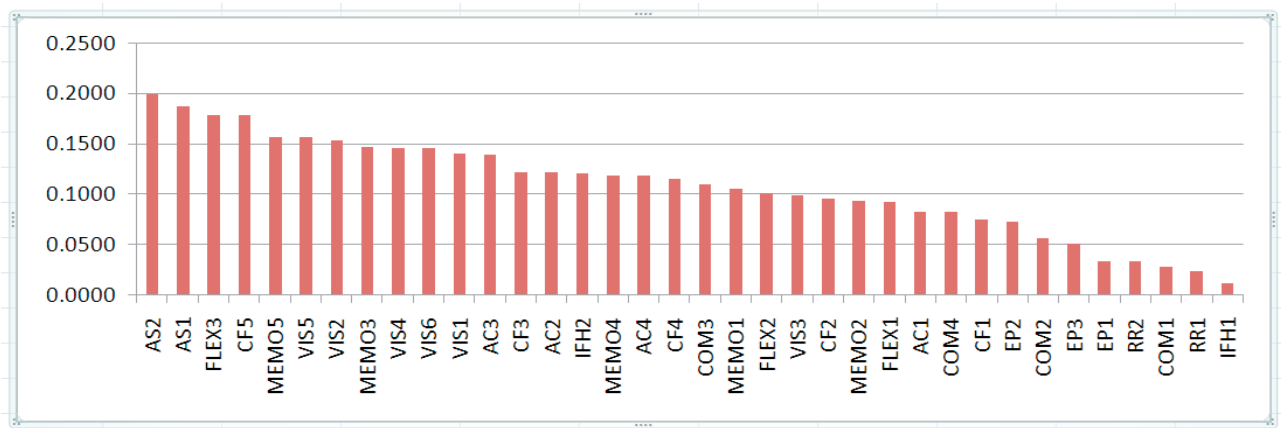

Gambar 3. Criticality Metric Ranking dari Item Uselearn

Tabel 5. Item Pertanyaan dengan Nilai Indeks Usability Terendah

\begin{tabular}{|c|c|c|c|}
\hline No & Dimensi & Item pertanyaan & Analisis \\
\hline 1 & IFH 1 & $\begin{array}{l}\text { Apakah situs E-learning } \\
\text { menawarkan kesempatan untuk } \\
\text { berinteraksi dan berkomunikasi } \\
\text { antara mahasiswa, dosen, dan isi } \\
\text { situs E-learning? }\end{array}$ & $\begin{array}{l}\text { IFH } 1 \text { mendapatkan nilai terendah karena jarang } \\
\text { sekali dosen yang bersangkutan memberikan } \\
\text { feedback dari tugas, jawaban untuk pertanyaan } \\
\text { yang terdapat pada forum diskusi di E-learning }\end{array}$ \\
\hline 2 & RR 1 & $\begin{array}{l}\text { Apakah kesulitan dalam } \\
\text { menggunakan } E \text {-learning } \\
\text { dapat berkurang dengan cara } \\
\text { memberikan pilihan menu yang } \\
\text { mudah dikenal? }\end{array}$ & $\begin{array}{l}\text { RR } 1 \text { memiliki nilai terendah kedua disebabkan } \\
\text { karena item menu yang terdapat di E-learning } \\
\text { mempunyai kemiripan bentuk antara satu } \\
\text { dengan yang lain, sehingga dirasakan sulit untuk } \\
\text { mengetahui manakah item yang sesuai dengan } \\
\text { pilihan tugas yang diinginkan }\end{array}$ \\
\hline 3 & COM 1 & $\begin{array}{l}\text { Apakah file mudah untuk di } \\
\text { download dan dilihat? }\end{array}$ & $\begin{array}{l}\text { COM } 1 \text { berada pada tingkat ketiga terendah } \\
\text { karena ketika mahasiswa akan men-download } \\
\text { file tersebut terbuka ditampilan E-learning, tidak } \\
\text { membuka di jendela baru. Sehingga ketika kita } \\
\text { mau kembali ke menu awal kita harus mengulang } \\
\text { dari awal dengan cara menekan tombol kembali } \\
\text { (back). }\end{array}$ \\
\hline 4 & RR 2 & $\begin{array}{l}\text { Apakah menu pilihan dalam } \\
\text { E-learning dapat dilihat dengan } \\
\text { mudah sehingga pengguna } \\
\text { tidak harus mencari menu } \\
\text { tersebut dan mencoba untuk } \\
\text { mengingatnya? }\end{array}$ & $\begin{array}{l}\text { RR } 2 \text { berada ditingkat keempat terendah karena } \\
\text { menu pilihan pada E-learning tidak semuanya } \\
\text { mudah dilihat, sehingga mahasiswa harus } \\
\text { mencari item menu yang dibutuhkan. Hal ini } \\
\text { membutuhkan waktu sedikit lebih lama yang } \\
\text { tentunya berpengaruh terhadap efisiensi. }\end{array}$ \\
\hline 5 & EP 1 & $\begin{array}{l}\text { Dapatkah pengguna mengerti } \\
\text { perintah dalam E-learning } \\
\text { dan menyelesaikannya dengan } \\
\text { mudah? }\end{array}$ & $\begin{array}{l}\text { EP } 1 \text { memiliki nilai terendah kelima disebabkan } \\
\text { karena mahasiswa masih bingung dengan bahasa } \\
\text { yang disajikan }\end{array}$ \\
\hline
\end{tabular}


menu baru yang mengharuskan dosen untuk memberikan jawaban dari tugas-tugas yang telah diberikan kepada mahasiswanya. Kemudian yang kedua adalah Reducing Redudancy1 (RR1) disebabkan karena banyaknya menu yang mirip bentuknya, sehingga dapat diperbaiki dengan memberikan icon-icon baru yang spesifik sesuai dengan label menu.

Terendah ketiga adalah Completeness 1 (COM1), disebabkan karena ketika mahasiswa akan mengunduh, data unduhan tersebut secara otomatis akan terbuka pada jendela browser tersebut (bukan pada jendela baru), sehingga mengharuskan mahasiswa untuk menekan tombol kembali untuk mengakses sesi terakhir. Hal ini bisa diperbaiki dengan mengubah pengaturan file tersebut ketika di klik langsung tersimpan di file unduhan atau langsung terbuka di jendela baru. Terendah keempat adalah Reducing Redudancy2 (RR2) disebabkan karena tidak semua pilihan menu dapat terlihat dengan mudah. Hal ini bisa diperbaiki dengan menempatkan menu yang dianggap penting pada tampilan layar, kemudian memperbesar ukuran menu tersebut. Terendah kelima adalah Error Prevention1 (EP1) karena mahasiswa mengalami kebingungan dengan bahasa blendedlearning. Hal ini dapat diperbaiki dengan mengubah bahasa akademis yang digunakan menjadi bahasa sehari-hari yang lebih mudah dimengerti dan lebih familiar.

\section{SIMPULAN}

Pada metode Uselearn ini didapatkan nilai indeks usability sesuai dengan hasil kuesioner melalui proses analisis EFA dan CFA. Metode ini menggunakan pengembangan dimensi usability dan kualitas. Pada metode Uselearn, pemilihan suatu item yang dianggap berkontribusi penting terhadap indeks usability dengan melihat nilai criticality metric. Hal ini dapat menghemat waktu dan usaha dalam menilai tingkat usability sebuah website E-learning. Dari hasil kuesioner didapatkan hasil terendah untuk criticality metric adalah Interactivity, feedback and Help 1 , sedangkan hasil yang tertinggi adalah untuk dimensi Assessment Strategy 1. Saran untuk penelitian selanjutnya, dapat mengembangkan nilai criticality metric sehingga kita mengetahui batas minimal suatu dimensi tersebut bisa dikatakan telah memenuhi kaidah indeks usability atau belum. Kemudian dari nilai indeks usability dapat didisagregatkan menjadi 3 nilai low-level dimensi yaitu efisiensi, efektif dan kepuasan. Sehingga dilakukan analisis lebih lanjut terhadap usability suatu E-learning.

\section{DAFTAR PUSTAKA}

Delio, M., 2000. Report: Online Training 'Boring', URL:: www.wired.com/news/business/0,1367,38504,00. html, diakses 10 Oktober 2014.

Dublin, L., and Cross, J., 2003. Implementing ELearning: Getting the Most From Your Elearning Investment, ASTD International Conference.

Harfoushi, O., AlFawwaz, B., Obiedar, R., Faris, H., and Al-Sayyed, R., 2012. Usability Asssessment of the Government Web Services in The Hashemite Kingdom of Jordan, Journal of American Science, 8(12), 340-352.

ISO 9241-11, 1998. Ergonomic Requirements for Office Work with Visual Display Terminals (VDTs) - Part 11: Guidance on Usability, International standards, First edition.

Matera, M., Costabile, M.F., Garzotto, F., and Paolini, P., 2002. SUE Inspection: an Effective Method for Systematic Usability Evaluation of Hypermedia, IEEE Transactions on Systems, Man, and Cybernetics Part A: Systems and Humans, 32 (1), 93-103.

McGee, M., 2004. Master Usability Scaling: Magnitude Estimation and Master Scaling Applied to Usability Measurement, CHI'04 Proceedings of The SIGCHI Conference on Human Factors in Computing Systems, 335-342.

Nielsen, J., 1993. Usability Engineering, Boston : Academic Press Professional.

Oztekin, A., Kong, Z.J., and Uysal, O., 2010. Uselearn: A Novel Checklist and Usability Method for Learning System by Criticality Metric Analysis, International Journal of Industrian Ergonomics, 40, 455-469.

Wahono, R. S., 2005. Pengantar E-learning dan Pengembangannya. URL:http://www. ilmukomputer.org/wp-content/uploads/2006/08/ romi-elearning1.zip, diakses 20 Juni 2014. 